\title{
Flux of debris transported by ice at three Alaskan tidewater glaciers
}

\author{
LEWIS E. HuNTER, \\ U.S. Army Cold Regions Research and Engineering Laboralory, Hanover, New Hampshire 03755, U.S.A. \\ Ross D. POWELL, \\ Department of Geology, Vorthern Illinois University, Dekalb, Illinois 6011.5, U.S.A. \\ DANIEL E. LAWSON \\ U.S. Army Cold Regions Research and Engineering Laboratory, Hanover, New Hampshire 03755, U.S.A.
}

\begin{abstract}
ABSTRAC'T. The stability of a tidewater terminus is controlled by glacial dynamics, calving processes and sedimentary processes at the grounding line. An investigation of grounding-line sediment dynamics and morainal-bank sediment budgets in Glacier Bay, Alaska, U.S.A., has vielded data that enable us to determine the debris fluxes of Grand Pacific, Margerie and Muir Glaciers. Debris flux ranges from $10^{5}$ to $10^{6} \mathrm{~m}^{3}$ a ${ }^{1}$, one to two orders of magnitude lower than the glacifluvial sediment fluxes $\left(10^{6}-10^{7} \mathrm{~m}^{3} \mathrm{a}{ }^{1}\right)$. Combined, these fluxes represent the highest yields known for glacierized basins. Large debris fluxes reflect the combined effects of rapid glacier flow, driven by the maritime climate of southeast Alaska, and highly erodible bedrock. Englacial-debris distribution is affected by valley width and relief, both of which control the availability of sediment. The number of tributaries controls the distribution and volume of debris in englacial and supraglacial moraines. At the terminus, iceberg-rafting removes up to two orders of magnitude more sediment from the ice-proximal environment than is deposited by melt-out or is dumped during calving events. Rough estimates of the sediment flux by deforming beds suggests that soft-bed deformation may deliver up to an order of magnitude more sediment to the terminus than is released from within the glacier ice,
\end{abstract}

\section{INTRODUCTION}

Although glaciers have long been recognized as significant agents of erosion and deposition (e.g. Playfair, 1802; Agassiz, 1840; Ramsay, 1862; Gilbert, 1905), little is known about the rates at which debris is transported and released at their termini. Modern and ancient moraine complexes, widespread till sheets, glacial outwash plains and massive offshore deposits attest to the effective mechanisms of glacial sediment transport. Modern process studies demonstrate that the accumulation of ice-proximal landforms varies according to the balance between the glacier sediment yield and the processes that control sediment deposition and redistribution near the terminus (e.g. Lawson, 1979; Powell, 1981; Hunter, 1994). It is now clear that this sediment balance influences ice-cliff stability in the marine environment (Mayo, 1988; Alley, 1991b; Powell, 1991; Hunter and Powell, in press b) by moderating grounding-line water depth Brown and others, 1982; Pelto and Warren, 1991). Therefore, an understanding of sediment transport and depositional processes not only helps us understand the formation of sedimentary facies, but should also be considered when studying the dynamics of tidewater glaciers.
Variables affecting glacial debris flux include sourcerock type, relief, weathering state and tectonic setting. Climate influences precipitation and temperature, which in turn influences the ice flux, thermal conditions and debris entrainment processes. Our study was located in the tectonically active region of Glacier Bay, Alaska, U.S.A. Fig. 1), where friable bedrock and unstable valley walls are the result of regional metamorphism, local metasomatism, deformation and fracturing (Powell, 1984b). Mountains in Glacier Bay reach elevations of over $4660 \mathrm{ma}$ a.s.l., where orographic precipitation and winds develop thick, often drifted, snow covers that nourish numerous glaciers Hunter, 1994). Local bedrock conditions combine with rapidly flowing glaciers to produce high sediment yields. Hallet and others in press) demonstrated recently that sediment yields in Glacier Bay correspond to effective denudation rates ranging from about 30 to $60 \mathrm{~mm} \mathrm{a}^{-1}$. Such rates are the highest yet reported in the literature for glacierized and non-glacierized basins (Milliman and Syvitski, 1992; Hallet and others, in press). Glacier Bay erosion rates are about an order of magnitude greater than those reported from southern Iceland $(3.8 \mathrm{~mm}$ a ': Lawler and others, 1992), Punjab Himalaya (1.4 $2.1 \mathrm{mma}^{-1}$ : Gardner and Jones, 1984), Central Asia (3-5 $\mathrm{mma}^{-1}$ : 


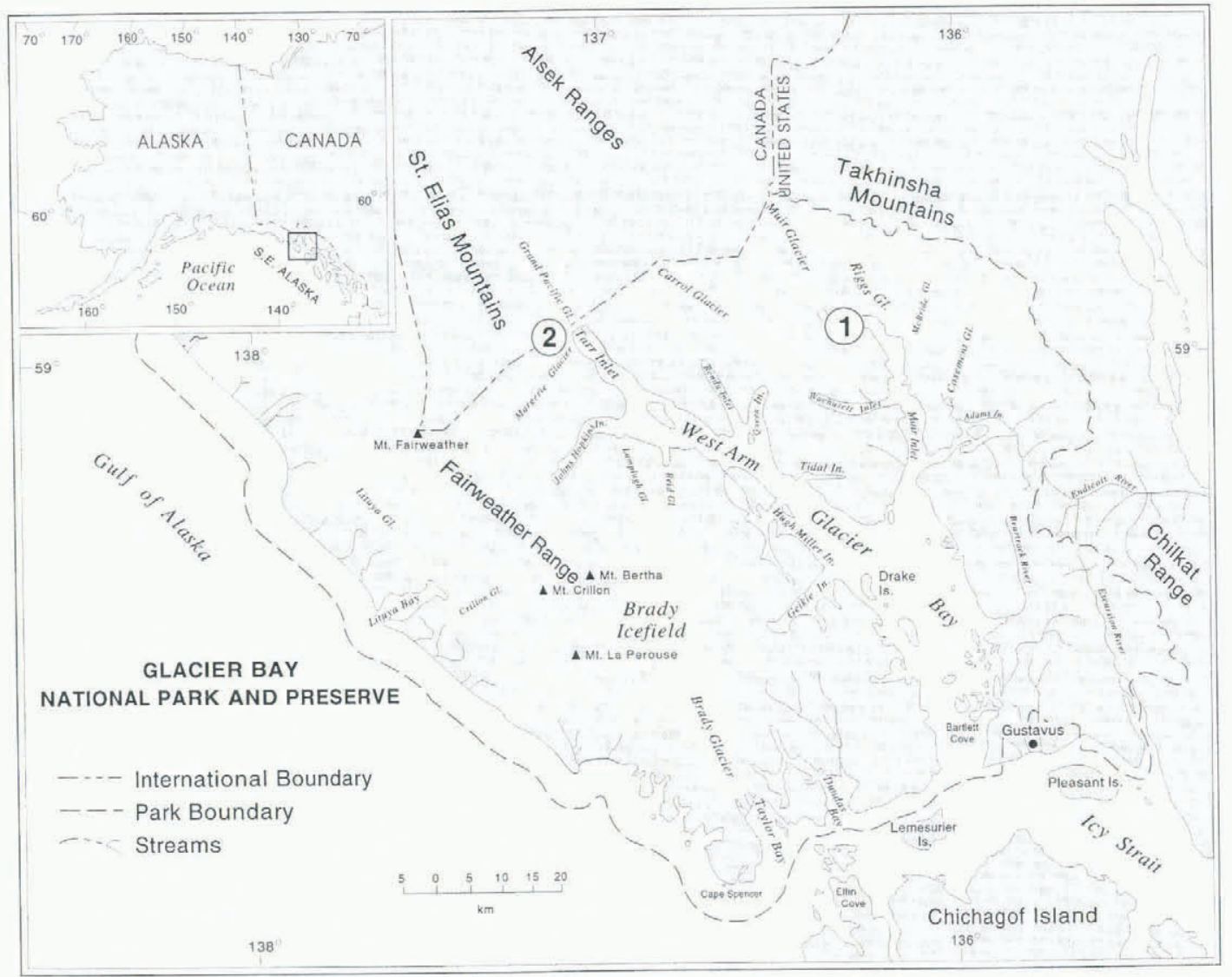

Fig. 1. Map of Glacier Bay. National Park and Preserve, showing the location of (1) Muir Glacier and (2) Grand Pacific and Margerie Glaciers.

Chernova, 1981) and the Ivory Basin, New Zealand (5.6 $\mathrm{mm} \mathrm{a}^{-1}$ : Hicks and others, 1990), and two orders of magnitude greater than Scandinavian glaciers $(\sim 0.1-$ $0.5 \mathrm{~mm} \mathrm{a}^{-1}$ : Bogen, 1989$)$.

Sediment released at the terminus is transported in the glacier by turbulent englacial and subglacial streams (e.g. Gustavson and Boothroyd, 1987; Lawson, 1993) and as debris in the ice. Debris transported in the basal and englacial zones is released through ablation at the terminus or grounding line, while supraglacial debris is mainly dumped during calving events (Powell, 1981). Some basal and englacial debris may be deposited away from the grounding line following transport by icebergs downfjord (e.g. Ovenshine, 1970; Dowdeswell and Dowdeswell, 1989; Dowdeswell and Murray, 1990; Gottler and Powell, 1990). Additional sediment transport may occur subglacially in a deforming layer e.g. Boulton, 1987; Boulton and Hindmarsh, 1987; Alley, $1991 \mathrm{a}$; Humphrey and others, 1993); but monitoring of this layer and measurement of its flux are difficult due to its inaccessibility.

A tidewater terminus is ideal for debris-flux analysis since an ice cliff represents a vertical cross-section through the glacier. Icebergs calving from above and below sea level (Fig. 2) eventually drift away from the ice cliff where they can be sampled. Ice from each stratigraphic horizon is collected to develop a composite stratigraphic section through the glacier. Selective sampling allows us to concentrate on defining the spatial distribution of debris so that the debris flux can be calculated. Our analysis differs from previous debris studies that have focused on
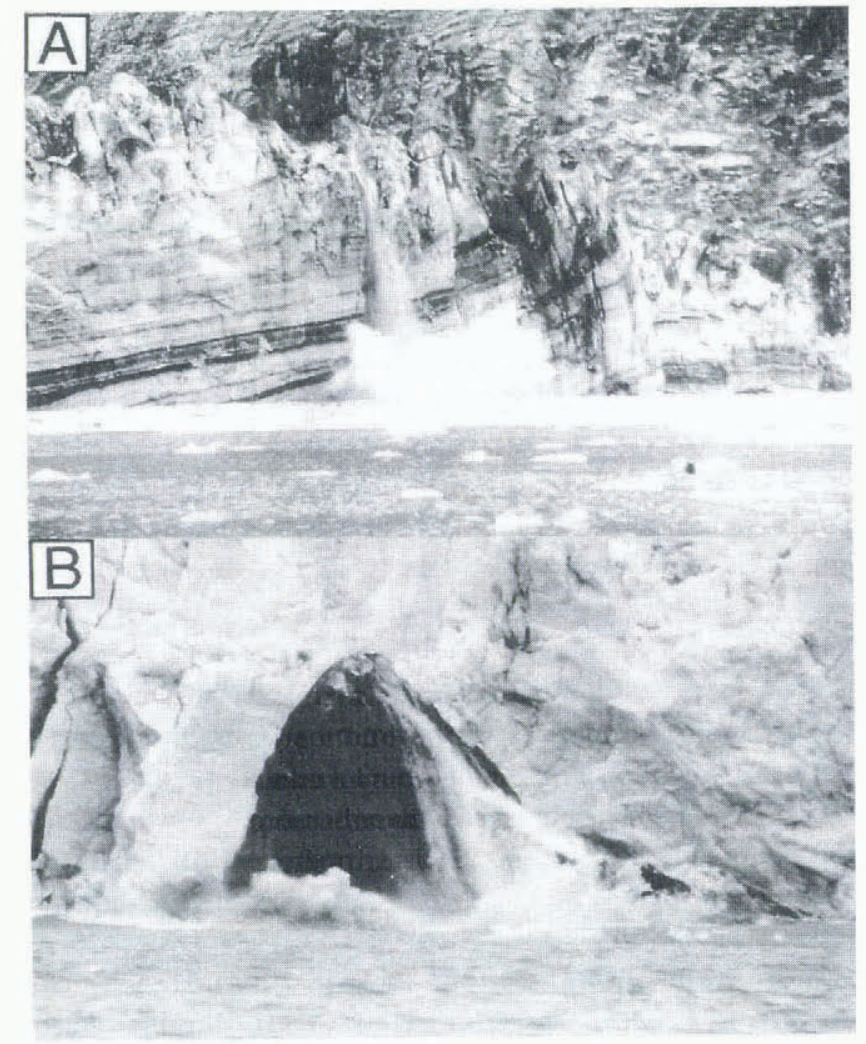

Fig. 2. Glacier calving process in Glacier Bay: (a) subaerial calving at Johns Hopkins Glacier, in which ice shallers upon impact with the water surface, and (b) submarine calving at McBride Glacier. Submarine icebergs tend to remain more-or-less inlact on reaching the water surface (photo from McBride Glacier by K. Seramur). 
demonstrating processes of debris entrainment and icefacies formation (e.g. Lawson, 1979; Knight, 1989; Hubbard, 1991; Gottler, 1992; Ronnert and Mickelson, 1992; Goodwin, 1993; Sharp and others, 1994; Souchez and others, 1994).

In this paper we describe the debris distribution in three tidewater glaciers Grand Pacific, Margerie and Muir) in Glacier Bay, Alaska Fig. 3), and evaluate their sediment yields, emphasizing the distribution of debris in and on the glaciers. Debris-flux estimates are useful for interpreting glacimarine records of the Gulf of Alaska e.g. Plafker and Addicott, 1976; Eyles and others, 1991 and perhaps for evaluating the minimum volume of ice required to distribute the large quantities of icebergrafted debris associated with Heinrich events in the North Atlantic e.g. Dowdeswell and others, 1995).

\section{TERMINOLOGY}

Terms used in this paper have been chosen for the purpose of modeling sedimentary processes along the marine grounding line of a tidewater terminus. A lidewater lerminus is a grounded vertical ice cliff of a glacier exposed to tidal activity Powell, 1988. We use grounding line to describe the boundary at the base of the ice cliff where it is in contact with the sea floor. Since sedimentary processes at the grounding line form a complex depositional svstem that extends away from the grounding line of. Powell. $1981,1984 b)$, it is appropriate to describe the depositional environment as the grounding-line system Powell, 1988). Sediment piles that accumulate in a bank geometry as part of grounding-line systems are called morainal banks (Powell, 1981, 1984a).

The glacifluvial and glacial components of the sediment budget are differentiated by reserving the term sediment for lithic material transported by fluvial or marine processes, the latter including debris once it has been relcased by melt-out or calving. Lithic material in transport in and on top of a glacier are referred to as debris Lawson, 1979). Therefore we describe glacial sediment fluxes as glacifluial sediment flux (sediment flux) and glacial debris flur (debris flux). Combined, the two fluxes represent the total glacier sediment yield of the basin, which we term tolal glacial sediment flux.

\section{SAMPLING PROCEDURES}

Debris concentrations were calculated for 282 iceberg samples and 139 glacier-ice samples (Fig. 4). The percentage of each facies exposed at each terminus was estimated in the field using a comparison chart for percentage composition (AGI, 1982) and subsequently bs

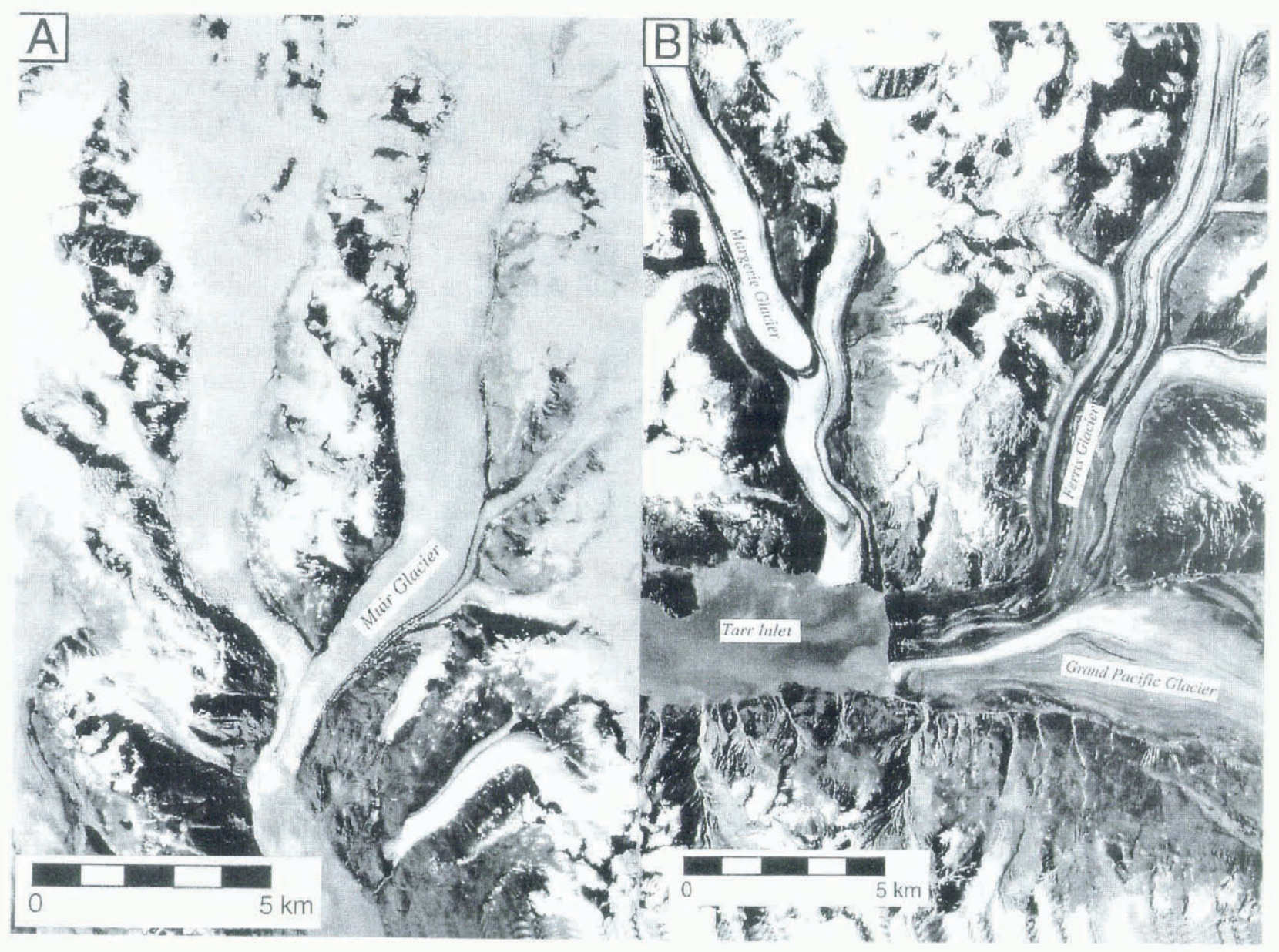

Fïg. 3. UII high-allitude aerial photographs of (a) Muir Glacier and (b) Grand Pacific. Ferris and Margerie Glaciers. laken in August 1979. The number of moraines reflects tributary confluence where debris reaches englacial-transport pathways in medial moraines that project into the glacier (courtess of the U.S. Geological Survey Ice and Cilimate Project. Tacoma. Washington). 


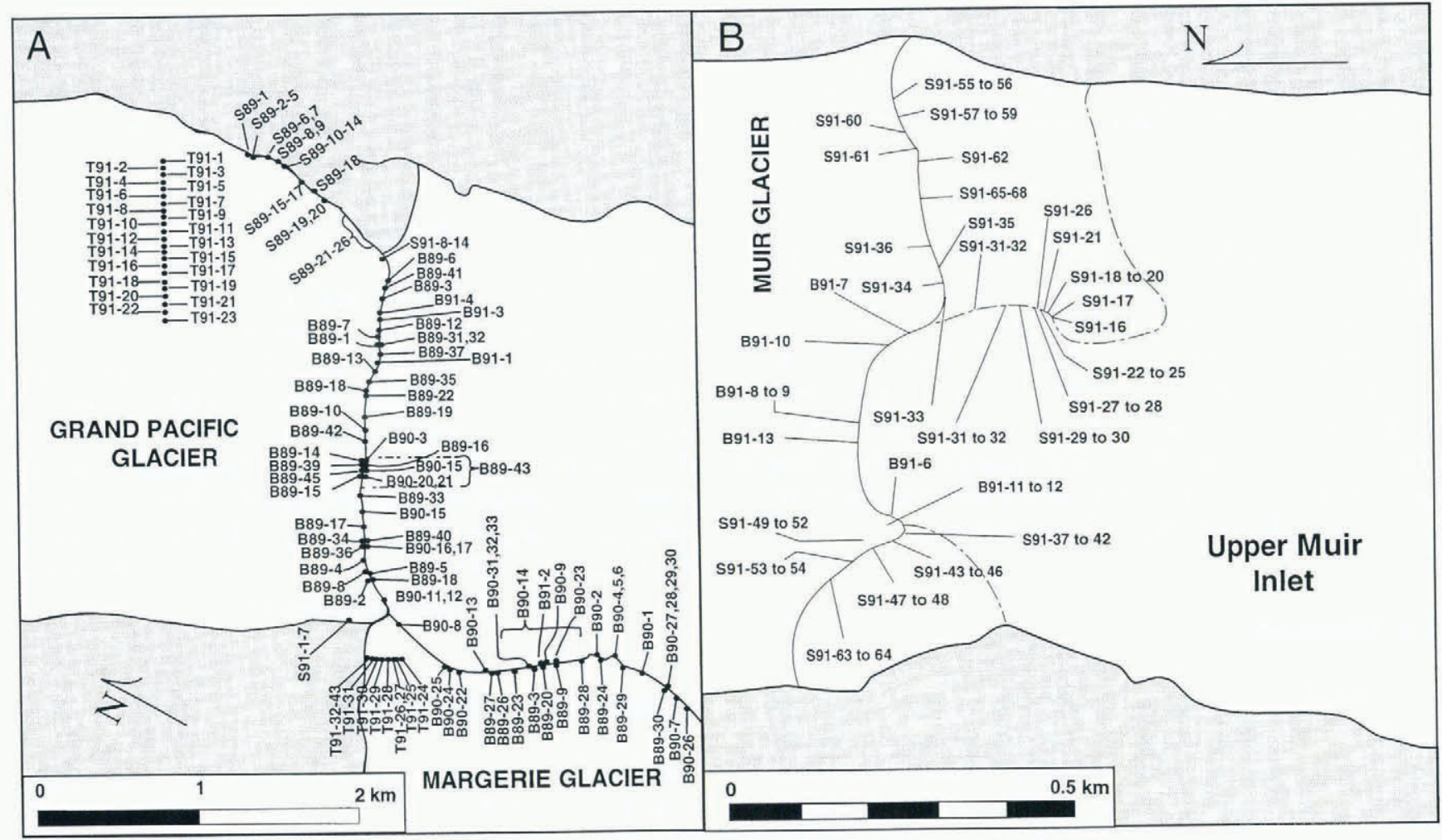

Fig. 4. Sites of iceberg and glacier-ice samples from (a) Grand Pacific and Margerie Glaciers, and (b) Muir Glacier. B, iceberg sample; S, glacier ice sample at terminus; T, glacier-ice sample collected along transects up-glacier from terminus.

point-count analyses of photographs. The thickness of basal stratigraphic sequences was determined from large icebergs that originate at the grounding line and from measurements at terrestrial exposures along these margins. Calving events originating below the water-line (Fig. 2b) produce large icebergs that do not fragment like those that topple or free-fall from subaerial parts of the ice cliff (Fig. 2a). These large icebergs often contain thick basal ice sequences that can be measured and sampled.

Englacial and basal ice samples were collected at exposures along the terminus and supraglacially along transects near the terminus (Fig. 4). Weathered surface ice was removed using an ice axe to expose fresh ice prior to the collection of each sample. All iceberg and glacierice samples were then described, crushed and melted before their volumes were measured for details, see Hunter, 1994). Samples were then allowed to settle before the meltwater was decanted and the sediments shipped to the laboratory for drying and weighing.

Debris concentration $C$; in volume fraction) of each ice sample was calculated by:

$$
C=V_{\mathrm{d}} /\left(V_{\mathrm{i}}+V_{\mathrm{d}}\right)
$$

where the ice volume $\left(V_{\mathrm{i}}\right)$ is

$$
V_{\mathrm{i}}=\left(V_{\mathrm{t}}-V_{\mathrm{d}}\right) 1.089
$$

using 1.089 to adjust for the reduction in volume when ice melts, $V_{\mathrm{t}}$ is the total sample volume, and $V_{\mathrm{d}}$ is the debris volume defined by

$$
V_{\mathrm{d}}=m / \rho_{\mathrm{d}}
$$

where $m$ is the mass and $\rho_{\mathrm{d}}$ is the density of the glacial debris as measured in the laboratory $2560 \pm 109 \mathrm{~kg} \mathrm{~m}^{3}$ at Grand Pacific Glacier, $2870 \pm 511 \mathrm{~kg} \mathrm{~m}^{-3}$ at Margerie Glacier and $2800 \pm 264 \mathrm{~kg} \mathrm{~m}^{-3}$ at Muir Glacier).

\section{Ice-facies analyses}

Debris-flux calculations depend on the identification of the characteristic ice facies that compose the glacier, measurements of debris concentrations, and appraisal of the percentage of each ice facies in the glacier. We use an ice-facies classification modified from Lawson (1979) that includes additional ice facies exposed in tidewater ice cliffs associated with medial moraines (Fig. 5). Lawson's original classification distinguishes ice facies by styles of debris suspension, concentration and zones of transport (englacial or basal). His classification consists of two englacial facies, the diffuse and banded, and two basal facies, the dispersed and stratified. The diffuse ice facies forms the greatest volume of the glacier and consists of white to light-blue, bubble-rich ice with an extremely low debris content $(<1 \%)$. Debris is suspended in the ice as isolated mud aggregates or silt and sand particles. Thin horizons with greater debris concentrations are called the banded ice facies and form a minor constituent of the glacier. We add a diffuse-stratified facies to describe pervasively foliated ice observed near the lateral margins of tidewater termini or in association with narrow bands of englacial ice confined by medial moraines.

For the debris-flux analyses, we assume that ice facies in the basal and morainal zones share similar processes of formation in the subglacial environment. Therefore, our distinction is based on glacier stratigraphy, where ice in the morainal zone reaches an englacial-transport path- 


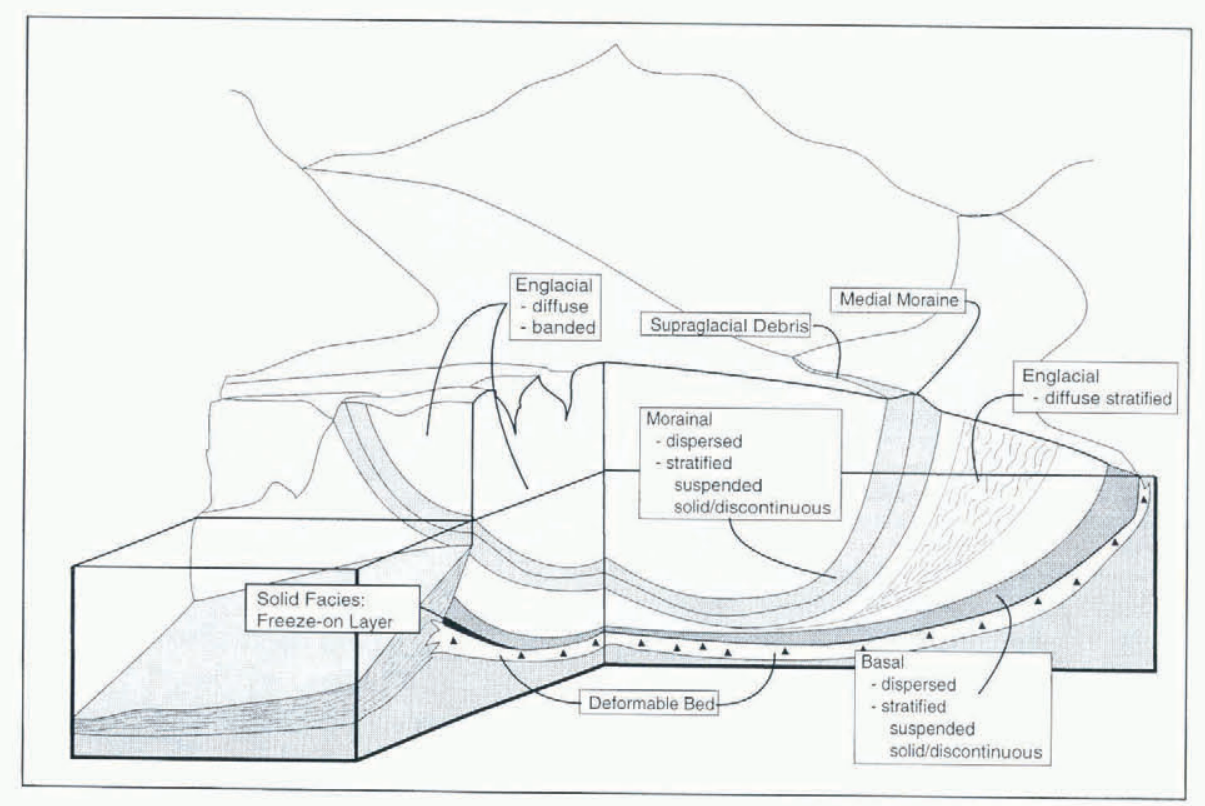

Fig. 5. General ice-facies distribution at a tidewater terminus (modified after Golller and Powell (1990)).

way by tributary confluence and the formation of medial moraines. The dispersed facies is generally transitional between englacial diffuse ice and the debris-rich horizons of the basal and morainal facies, and consists of blue ice that is generally bubble-free to bubble-poor, with debris concentrations slightly higher (mean about 4 5\%) than englacial ice (Lawson and Kulla, 1978; Lawson, 1979). The stratified ice facies is debris-rich and forms the lowermost horizons in the basal zone and the core of moraines. This facies is divided into three subfacies based on the distribution of sediment in the ice. The suspended subfacies consists of relatively clear, bubble-free ice within which are suspended sand, silt, pebble-size particles and aggregates. The discontimuous subfacies consists of thin, discontinuous debris-rich lenses and laminae separated by thin clear-ice laminae. The solid subfacies consists of frozen debris held together by interstitial ice, and may occasionally exhibit primary sedimentary structures.

\section{Englacial ice facies}

The diffuse facies is dominated by white, bubbly ice that comprises $65-83 \%$ of the ice in the termini of Grand Pacific, Margerie and Muir Glaciers (Fig. 6a; Table 1 ). Debris occurs as isolated sand and silt particles, silty mudfilled bubbles and rare cobbles and boulders with concentrations in the diffuse facies ranging from trace values to $0.9 \%$ Hunter, 1994). The highest average debris concentration of diffuse facies occurs at Muir Glacier $0.6 \%$ by volume), whereas average concentrations at Margerie and Grand Pacific Glaciers are about $0.2 \%$ and $0.1 \%$ by volume, respectively (Table 1 ).

Diffuse-stratified facies occurs in zones of pervasively foliated englacial ice (Fig. 6b). Bulk sampling vielded debris concentrations of $0.4-14.4 \%$ by volume. The diffuse-stratified facies is most abundant at Grand Pacific Glacier where it comprises up to $7.1 \%$ of the terminus and has an average debris concentration of $2.7 \%$ by volume (Table 1). At Margerie and Muir Glaciers, this facies is a minor component $(<2 \%)$ of the ice cliff and contains up to $1.4 \%$ debris by volume.
Banded facies constitutes a small percentage $<1 \%$; Table 1) of ice cliffs and is characterized by thin debrisrich horizons. This facies is poorly developed at Margerie and Muir Glaciers where thin up to a few millimeters) horizons have debris concentrations of $0.2 \quad 0.4 \%$ by volume. At Grand Pacific Glacier, similar horizons are up to $3 \mathrm{~cm}$ thick with concentrations ranging from $1.7 \%$ to $27.1 \%$ by volume. Debris horizons are commonly stratified, consisting of debris-rich bands separated by clear-ice layers. Debris in these bands is in the form of suspended sand-particle and mud clots (Heiny, 1983). At higher concentrations, the debris occurs in lenses and more continuous strata with only interstitial ice.

\section{Basal-zone and morainal ice facies}

Morainal and basal-ice stratigraphic sequences are composed of dispersed and stratified facies. Morainal sequences contain ice facies similar to those in the basal zone, but the facies are often repeated on both sides of a central debris-rich horizon, and the dispersed facies may be absent in morainal sequences. Morainal sequences appear to represent condensed basal sequences Lawson, 1979 that range from a few meters to much thicker sequences, as at Grand Pacific Glacier where the sequence marking the boundary of the Ferris tributary is $30 \mathrm{~m}$ wide and includes a $1 \mathrm{~m}$ thick debris-rich horizon of Lawson's (1979) solid subfacies.

The dispersed facies is characterized by low average debris concentrations ranging from about $0.1 \%$ to $1.4 \%$ by volume (Table 1). A sharp contact between the englacial diffuse and basal dispersed ice (Fig. 6c) is generally discordant with glacial sedimentary layering and ice-banding. Debris is dispersed in the form of isolated particles and aggregates that occur predominantly at grain boundaries.

Basal and morainal stratified facies constitute 4.3 $10.4 \%$ of the ice observed (Table 1). The discontinuous subfacies is characterized by alternating thinly laminated debris-rich and clear ice (Fig. 6d). Debris horizons range from a few sand grains to several centimeters thick, and 


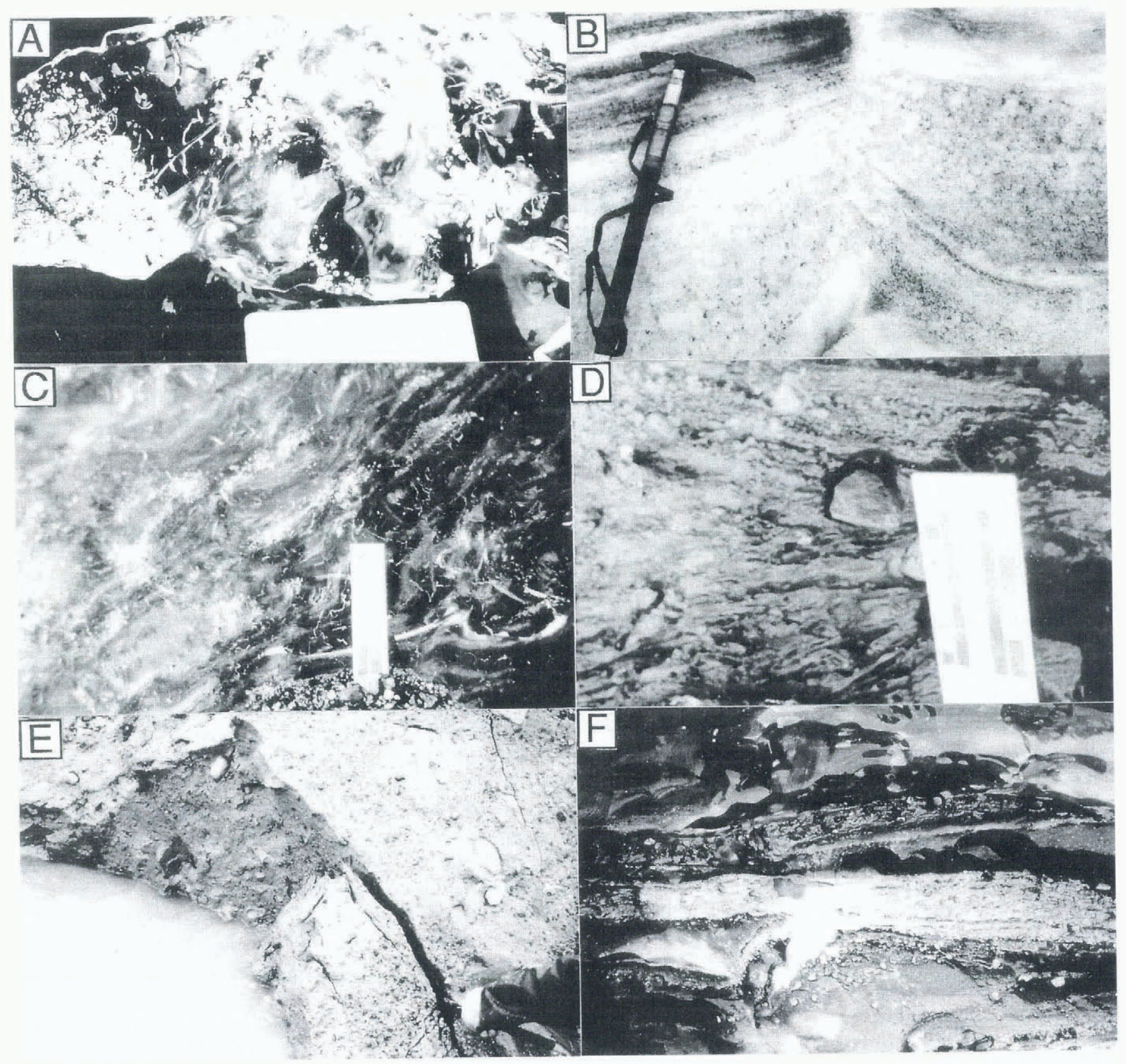

Fig. 6. Ice facies observed at lidewater termini in Glacier Bay: (a) bubbly englacial diffuse, (b) englacial diffusestratified, (c) basal dispersed, (d) basal discontimuous subfacies, (e) basal solid subfacies, and ( $f$ ) alternating layers of debris-rich discontinuous subfacies and debris-poor suspended subfacies.

form lenses of various lengths in each debris-rich horizon. Clear-ice laminae are bubble-free, with minor amounts of suspended silt and sand particles.

Solid subfacies are generally devoid of clear-ice laminae and are composed of debris horizons greater than $1 \mathrm{~cm}$ thick. Interstitial ice-crystal growth is confined in the fine pore structure of silty muds that exhibit a frosty (ice-cement) luster on freshly broken surfaces. Boulton (1970) and Lawson (1979) have described sedimentary structures in solid layers that indicate possible incorporation at the glacier sole by freeze-on and vertical accretion (Lawson and Kulla, 1978; Lawson, 1979) or perhaps by fluvial sediments deposited in basal-zone conduits.

Thick horizons of solid subfacies have been observed at the stratigraphic bases of icebergs that originated below sea level in contact with the sea floor (Fig. 6e).
These horizons are composed of diamictons similar to those described by Powell and Molnia (1989) and Gottler and Powell (1990), but they melt rapidly or break off icebergs and sink. Where solid layers have been observed in an iceberg, they form anisotropies along which icebergs tend to break. At Margerie Glacier, subglacial debris fills flutes up to a few tens of centimeters deep) on the surface of icebergs that had previously been in contact with the sea floor (Fig. 7). Solid layers at Muir Glacier are composed of well-sorted and well-rounded sand and gravel apparently derived from fluvial sediments in the morainal bank (Hunter, 1994). Solid subfacies resulting from seasonal freeze-on of saturated sediments have been observed in basal ice sequences of Gulkana, Matanuska and Kennicott Glaciers in southern Alaska, and Findeln and Z'Mutt Gletchers in the Swiss Alps (Lawson, 
Table I. Summary of azerage debris calculations. $\bar{x}$, average debris concentration with $1 \sigma \mathrm{in} \mathrm{kg} \mathrm{m}^{3}$; $\%$, representative percenlage of each ice facies in ice cliff; Vol, colume fraction of debris in concentration

\begin{tabular}{|c|c|c|c|c|c|c|c|c|c|c|c|c|}
\hline \multirow[b]{2}{*}{ Ice facies } & \multicolumn{4}{|c|}{ Muir Glacier } & \multicolumn{4}{|c|}{ Margerie Glacier } & \multicolumn{4}{|c|}{ Grand Pacific Glacier } \\
\hline & & $\bar{x}$ & $\%$ & Vol & & $\bar{x}$ & $\%$ & Vol & & $\bar{x}$ & $\%$ & Vol \\
\hline \multicolumn{13}{|l|}{ Englacial } \\
\hline Diffuse & $16.8=$ & \pm 3.0 & 83.0 & 0.6 & 8.0 & \pm 8.0 & 80.0 & 0.2 & 2.5 & \pm 2.4 & 64.8 & 0.1 \\
\hline Diffuse-stratified & $42.5=$ & \pm 4.5 & 2.0 & 1.4 & 45.1 & \pm 35.3 & 0.9 & 1.3 & 74.0 & \pm 85.3 & 7.1 & 2.7 \\
\hline Banded & $12.1=$ & \pm 0.6 & 0.7 & 0.4 & 5.9 & \pm 0.3 & 0.1 & 0.2 & 339.0 & \pm 285.4 & 0.7 & 12.2 \\
\hline \multicolumn{13}{|l|}{ Morainal } \\
\hline Dispersed & $20.1=$ & \pm 5.4 & - & - & 2.3 & \pm 3.3 & 0.1 & $\sim 0.1$ & 1.4 & \pm 1.4 & 6.1 & 1.4 \\
\hline Suspended & $116.7=$ & \pm 69.7 & 0.8 & 3.9 & 33.3 & \pm 43.5 & 2.3 & 0.9 & 105.1 & \pm 113.7 & 3.6 & 3.8 \\
\hline Discontinuous/solid & $509.4=$ & \pm 236.1 & 0.6 & 17.0 & 406.9 & \pm 270.3 & 0.2 & 9.8 & 626.1 & \pm 426.7 & 2.2 & 22.4 \\
\hline \multicolumn{13}{|l|}{ Basal } \\
\hline Dispersed & 20.1 & \pm 5.4 & 10.0 & 0.7 & 2.3 & \pm 3.3 & 9.5 & $\sim 0.1$ & 1.4 & \pm 1.4 & 11.0 & 1.4 \\
\hline Suspended & 116.7 & \pm 69.7 & 1.8 & 3.9 & 33.3 & \pm 43.5 & 2.6 & 0.9 & 105.1 & \pm 113.7 & 2.1 & 3.8 \\
\hline Discontinuous/solid & 509.4 & \pm 236.1 & 1.1 & 17.0 & 406.9 & \pm 270.3 & 3.6 & 9.8 & 626.1 & \pm 426.7 & 2.5 & 22.4 \\
\hline Freeze-on & 1433.2 & \pm 232.4 & 1422 & $\mathrm{NA}$ & & & & & & 1933.5 & XI & 69.5 \\
\hline
\end{tabular}

unpublished data). Solid subfacies contain up to $70 \%$ debris by volume Table 1 ).

The suspended subfacies Fig. 6f consists of ice layers about $1 \mathrm{~cm}$ to over $3 \mathrm{~m}$ thick. This subfacies was a minor
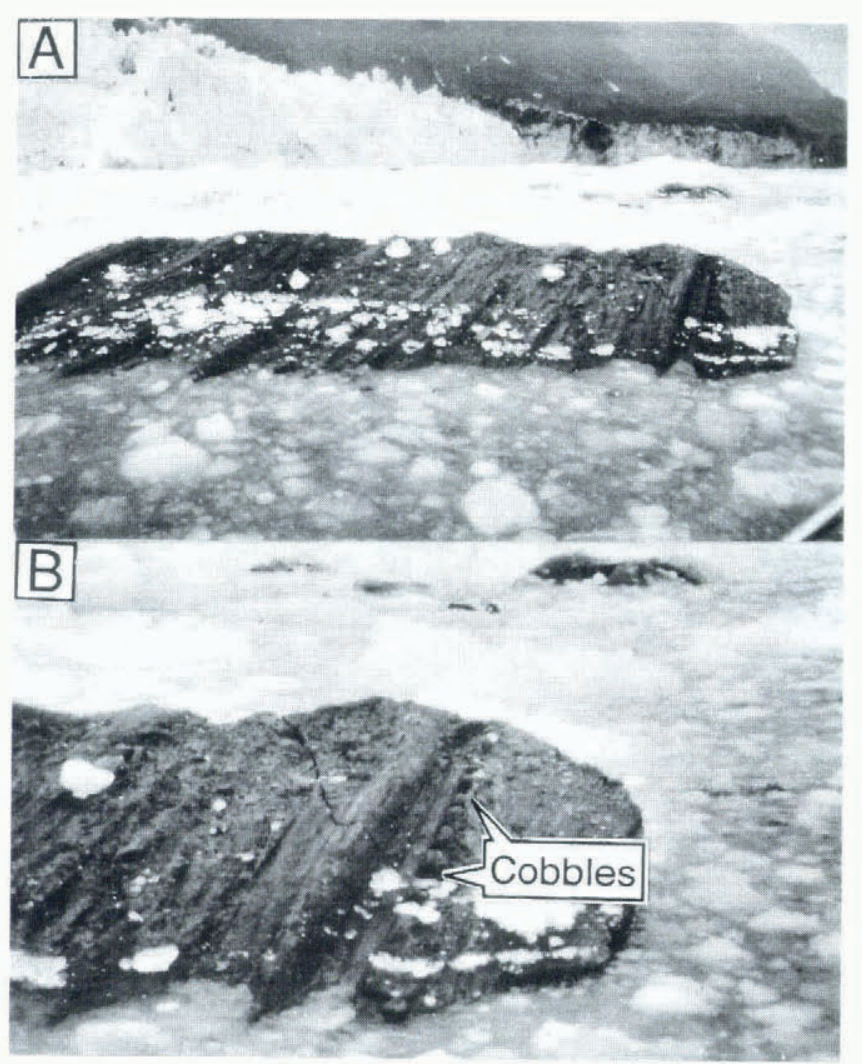

Fig. 7. Glacier-sole morphology preserved on a submarine iceberg that calved from Margerie Glacier. (a) . Nole linear fluting across face of berg. (b) Cilose-up of right edge of berg shown in (a), highlighling surface lexlure and row of cobbles that are aligned clast to clast. constituent $2.6-5.7 \%$; Table 1$)$ of the three tidewater termini, with debris concentrations less than $0.1-12.6 \%$ by volume Hunter, 1994). Debris is suspended as isolated silt, sand and gravel particles, and commonly forms sandy-mud aggregates.

\section{Debris flux of Grand Pacific, Margerie and Muir Glaciers}

Compilation of the ice-facies data Table 1 gives us the opportunity to calculate the total volume of debris transported to the terminus. The debris concentrations of each facies and their percentage in an ice cliff Tables I and 2 are used to calculate the debris flux $\left(D_{t}\right)$ for the different glaciers by the simple relationship:

$$
D_{\mathrm{t}}=D_{\mathrm{g}}+D_{\mathrm{s}}
$$

where $D_{\mathrm{s}}$ is the supraglacial debris flux i.e. surface transport and $D_{g}$ is the debris flux within basal and englacial ice facies calculated using:

$$
D_{\mathrm{g}}=Q_{\mathrm{i}} \sum_{j=1}^{n} C_{j} V_{j}
$$

so that $D_{\mathrm{g}}$ is the product of the ice flux $\left(Q_{\mathrm{i}}\right)$ and the sum of the debris concentrations $(C)$ of each ice facies weighted by their relative volume $V_{j}$ in the ice cliff: The ice flux is:

$$
Q_{\mathrm{i}}=v_{\mathrm{t}} w h_{1}
$$

where $v_{1}$ is the averaged surface velocity near the terminus as estimated from acrial photographs, $w$ is the glacier width, and $h_{t}$ is the height of the ice cliff (Table 3). This calculation assumes that ice flow near the glacier terminus occurs as a plug with little internal deformation. We assume that the observed surface velocity is due 


\begin{tabular}{|c|c|c|c|c|c|c|c|c|c|c|}
\hline \multirow[b]{2}{*}{ Ice facies } & \multicolumn{4}{|c|}{ Muir Glacier ${ }^{\dagger}$} & \multicolumn{3}{|c|}{ Margerie Glacier } & \multicolumn{3}{|c|}{ Grand Pacific Glacier ${ }^{\dagger}$} \\
\hline & $D_{\mathrm{t}}$ & $D_{\mathrm{m}}$ & $D_{\mathrm{c}}$ & $D_{\Delta}$ & $D_{\mathrm{t}}$ & $D_{\mathrm{m}}$ & $D_{c}$ & $D_{\mathrm{t}}$ & $D_{\mathrm{m}}$ & $D_{\mathrm{c}}$ \\
\hline \multicolumn{11}{|l|}{ Englacial } \\
\hline Diffuse & 65.0 & 3.9 & 35.2 & 25.9 & 25.9 & 1.0 & 24.8 & 3.6 & 0.2 & 3.0 \\
\hline Diffuse-stratified & 3.8 & 0.02 & 2.1 & 1.7 & 1.6 & 0.1 & 1.5 & 11.7 & 0.5 & 9.8 \\
\hline Banded & 0.4 & TR & 0.2 & 0.2 & 0.03 & TR & 0.02 & 5.3 & 0.2 & 4.4 \\
\hline \multicolumn{11}{|l|}{ Morainal } \\
\hline Dispersed & - & & - & & TR & TR & TR & 5.2 & 0.2 & 4.4 \\
\hline Suspended & 4.2 & 0.03 & 2.4 & 1.8 & 2.9 & 0.1 & 2.8 & 8.4 & 0.4 & 7.1 \\
\hline Discontinous/solid & 13.8 & 0.09 & 7.7 & 6.0 & 3.4 & 0.1 & 3.2 & 30.5 & 1.4 & 25.7 \\
\hline \multicolumn{11}{|l|}{ Basal } \\
\hline Dispersed & 9.0 & 0.06 & 5.1 & 3.9 & 1.2 & TR & 1.2 & 9.5 & 0.4 & 8.0 \\
\hline Suspended & 9.5 & 0.06 & 5.3 & 4.1 & 3.4 & 0.1 & 3.3 & 4.9 & 0.2 & 4.1 \\
\hline Discontinous/solid & 25.3 & 1.6 & 14.2 & 9.5 & 5.8 & 2.2 & 56.1 & 34.6 & 1.5 & 29.2 \\
\hline Total & 131.0 & 5.8 & 72.2 & 53.1 & 96.7 & 3.7 & 93.0 & 113.7 & 5.0 & 95.7 \\
\hline \multicolumn{2}{|c|}{ Supraglacial debris flux } & \multicolumn{3}{|c|}{1.4} & \multicolumn{4}{|c|}{4.1} & \multicolumn{2}{|c|}{3.4} \\
\hline \multicolumn{2}{|l|}{ Basal freeze-on } & \multicolumn{3}{|c|}{72} & \multicolumn{4}{|c|}{1.0} & \multicolumn{2}{|c|}{62} \\
\hline
\end{tabular}

* Values are $10^{4} \mathrm{~m}^{3} \mathrm{a}^{-1}$

† Average ice-cliff water depth of $18.8 \mathrm{~m}$ used to calculate $D_{\mathrm{m}}$.

\$ Termini width exposed to tidewater used to calculate $D_{\mathrm{m}}$.

Table 3. Glacier parameters during study (1988-91)

\begin{tabular}{|c|c|c|c|c|c|c|}
\hline \multirow[b]{2}{*}{ Variable } & \multirow[b]{2}{*}{ Symbol } & \multirow[b]{2}{*}{ Unil } & \multicolumn{2}{|c|}{ Grand Pacific Glacier } & \multirow[t]{2}{*}{ Margerie Glacier } & \multirow[t]{2}{*}{ Muir Glacier } \\
\hline & & & Ferris tribulary & Grand Pacific Iribulary & & \\
\hline Average velocity & $v$ & $\mathrm{ma}^{-1}$ & 380 & 158 & 679 & 1700 \\
\hline Terminus velocity & $v_{\mathrm{t}}$ & $\mathrm{ma}^{-1}$ & 525 & 110 & 810 & 1700 \\
\hline Calving speed & $v_{\mathrm{c}}$ & $\mathrm{ma}^{1}$ & 480 & 69 & 776 & 1770 \\
\hline Glacier width & $w$ & $\mathrm{~m}$ & 1620 & 950 & 1900 & 880 \\
\hline Calving width & $w_{\mathrm{c}}$ & $\mathrm{m}$ & 1620 & 220 & 1900 & 475 \\
\hline Average water depth & $h_{\mathrm{w}}$ & $\mathrm{m}$ & 20 & 10 & 30 & 30 \\
\hline Average total cliff height & $\mathrm{t} \quad h_{\mathrm{t}}$ & $\mathrm{m}$ & 66 & 54 & 90 & 90 \\
\hline Advance rate & $T$ & $\mathrm{ma}^{-1}$ & 24 & 20 & 10 & 0 \\
\hline
\end{tabular}

mostly to rapid basal sliding, as observed at another calving glacier in southern Alaska, Columbia Glacier (Humphrey and others, 1993).

Calculations of $Q_{\mathrm{i}}$ for Margerie and Muir Glaciers yielded ice fluxes of $1.38 \times 10^{8}$ and $1.35 \times 10^{8} \mathrm{~m}^{3} \mathrm{a}^{-1}$, respectively. The ice flux at Grand Pacific Glacier $\left(0.62 \times 10^{8} \mathrm{~m}^{3} \mathrm{a}^{-1}\right)$ is half as large because of the glacier's slower flow (Table 3). By solving Equation (5) for each glacier we estimate debris fluxes of $1.3 \times 10^{6} \mathrm{~m}^{3} \mathrm{a}^{1}$ (Muir Glacier), $9.7 \times 10^{5} \mathrm{~m}^{3} \mathrm{a}^{-1}$ (Margerie Glacier) and $1.1 \times 10^{6} \mathrm{~m}^{3} \mathrm{a}^{-1}$ (Grand Pacific Glacier; Table 2).

Comparison of these estimates demonstrates the influence of debris distribution and ice-flow rates on the debris flux. Muir and Margerie Glaciers transport less debris per unit volume than Grand Pacific Glacier (Table 1); however, Muir Glacier has the highest debris flux, due to its large ice flux (Table 2). Alternatively, despite the low ice flux of Grand Pacific Glacier, its debris flux is about 30\% greater than that of Margerie Glacier because of its higher debris concentrations. Margerie Glacier's debris concentrations are about $60 \%$ per unit volume of Muir Glacier's. The concentration and distribution of debris alone are not enough to produce a high debris flux, but when combined with rapid glacier flow, exceptionally high rates of debris transfer to the grounding line can occur.

Supraglacial debris flux was calculated as the product of glacier surface velocity, moraine widths measured 
photogrammetrically and surficial debris thickness measured in the field. Moraine thicknesses observed during transects of Margeric and Grand Pacific Glaciers (Fig. 4) ranged from less than $1 \mathrm{~mm}$ to $1.5 \mathrm{~m}$ (Hunter, 1994), and were generally less than the $0.08 \mathrm{~m}$ estimate of Gottler (1992) at McBride Glacier. A debris cover of about $1 \mathrm{~mm}$ is sufficient to discolor the surface while a thickness of 1 $2 \mathrm{~cm}$ appears to form a complete cover on aerial photographs (e.g. Fig. 3). Thicker moraine cover 0.5 $1.0 \mathrm{~m}$ ) fills surface crevasses and forms debris ridges and rounded gravel surfaces. Despite the conspicuous appearance of supraglacial moraines (Fig. 8), their fluxes are relatively low: $3.4 \times 10^{4} \mathrm{~m}^{3} \mathrm{a}^{-1}$ at Grand Pacific Glacier, $4.1 \times 10^{4} \mathrm{~m}^{3} \mathrm{a}^{-1}$ at Margerie Glacier and $1.4 \times 10^{4} \mathrm{~m}^{3} \mathrm{a}$ at Muir Glacier (Table 2). Supraglacial debris is assumed to be released entirely by various gravitational processes at tidewater ice cliffs; however, some is also released on the heads of fan deltas along terrestrial parts of the margins (e.g. the northern edge of Margerie Glacier and the eastern margin of Grand Pacific Glacier).

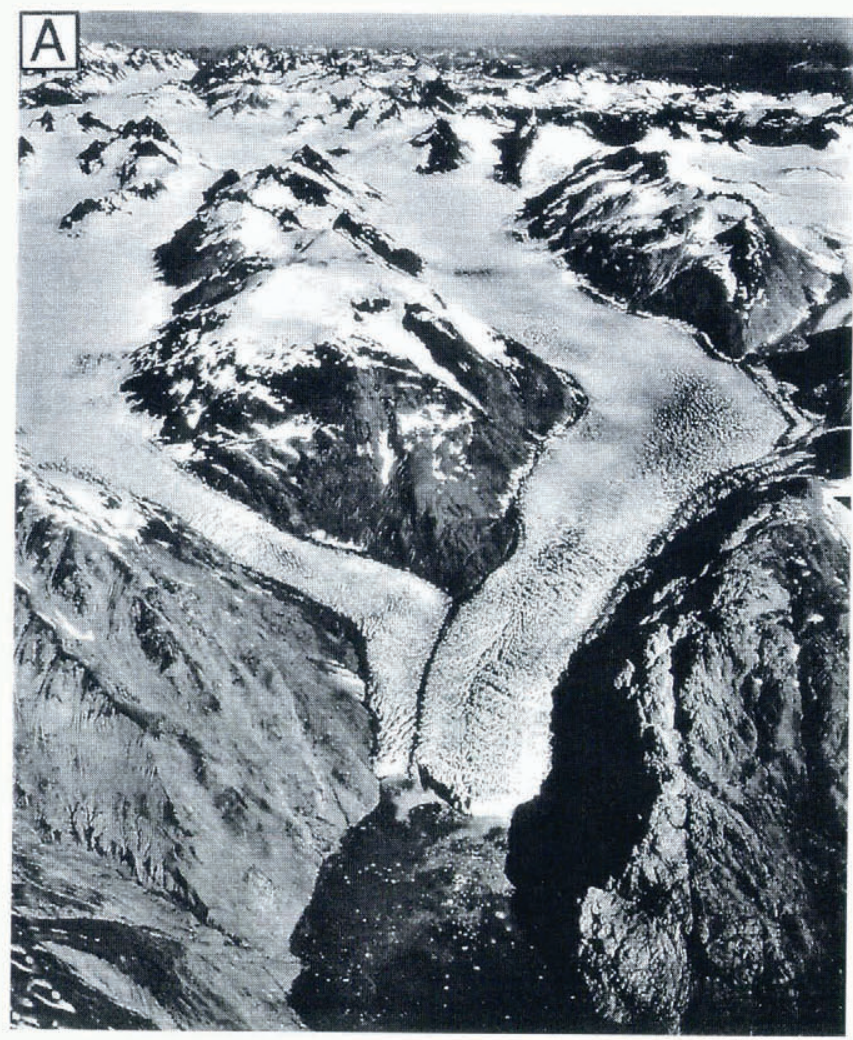

C

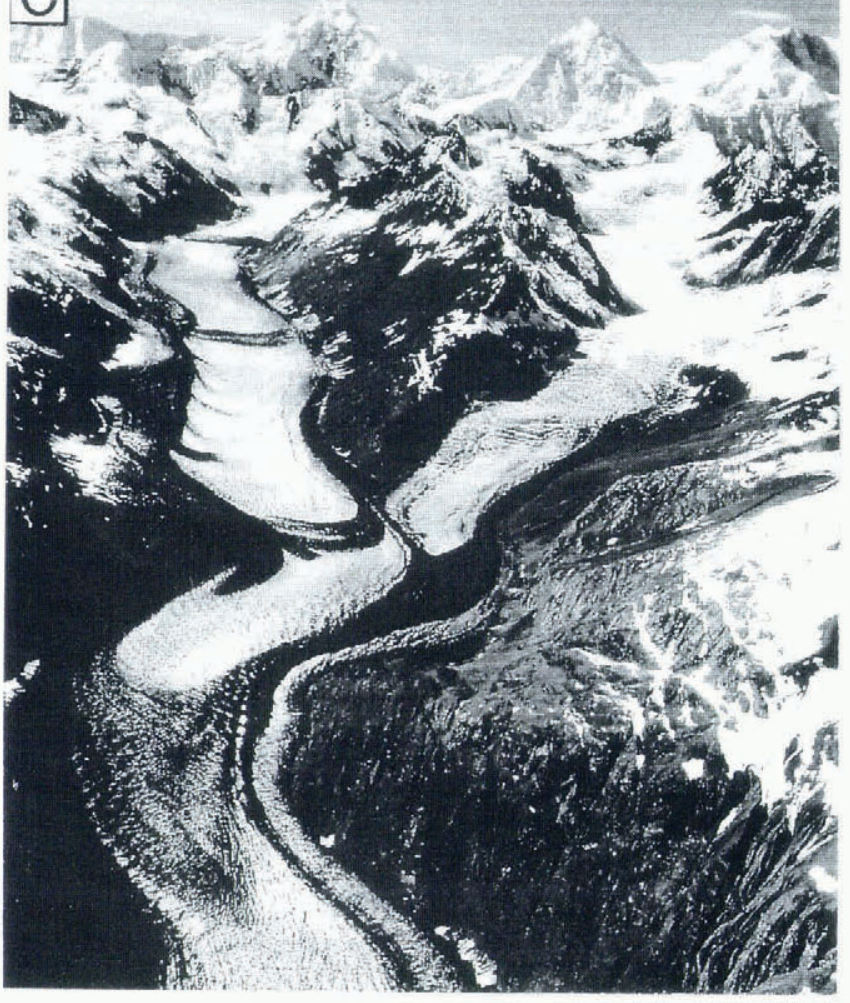

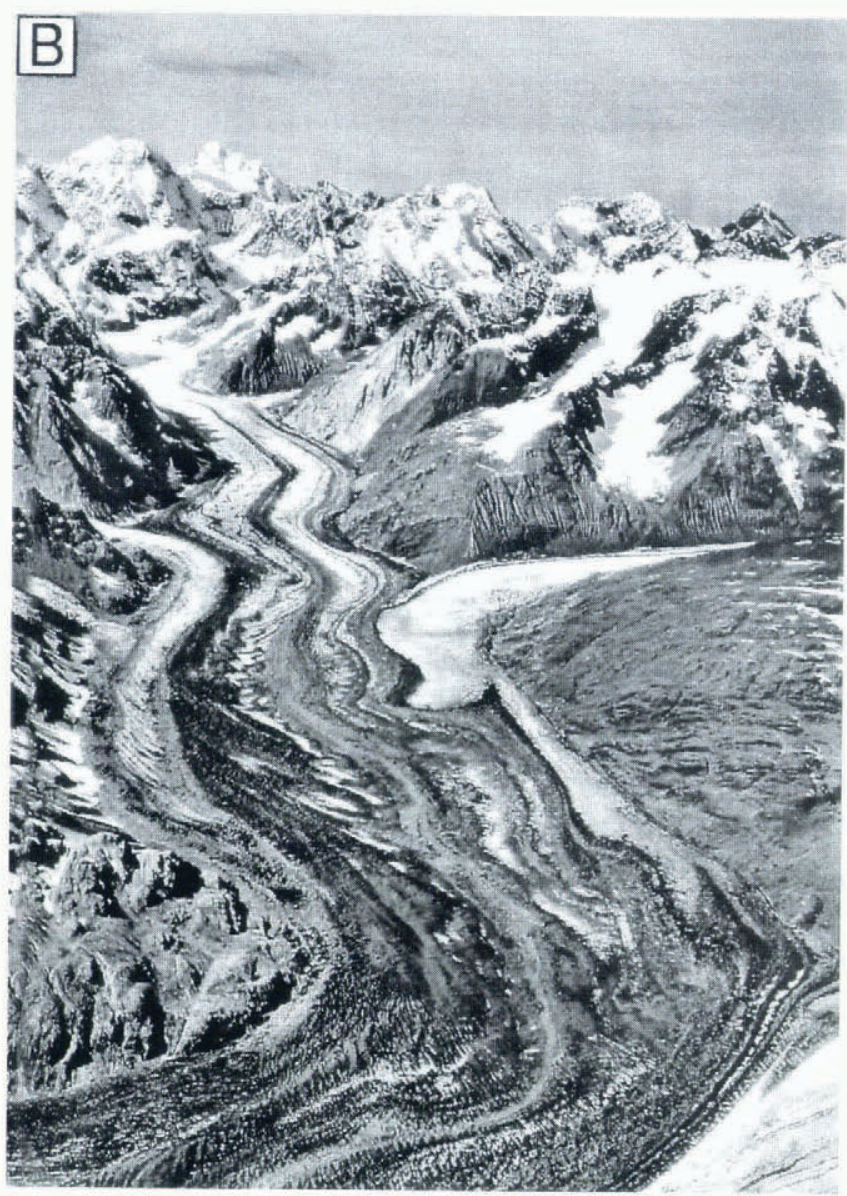

Fig. 8. Oblique aerial photos of (a) Muir Glacier, (b) Ferris tribulary to Grand Pacific Glacier, and (c) Margerie Glacier. The number and complexity of tributaries, local relief and valley width and area-elezation distribution relative to zones of maximum snowfall influence debris distribution (see lexl for descriplion: pholographs by A. Post, (T.S. Geological Survey). 


\section{DISCUSSION}

Debris-llux estimates provide some indication of the role various factors play in determining the transport of debris by tidewater glaciers. The differences in debris distributions and fluxes between Muir, Grand Pacific and Margerie Glaciers indicate that valley geometry, especially width, glacier flow speed and the number of tributary glaciers flowing into the main trunk glacier, strongly influence debris flux. Grand Pacific and Margerie Glaciers are larger and wider than Muir Glacier (Table 3; Figs 3 and 8); the apparent result is that debris is more easily distributed across Muir Glacier by slope mass movement and eolian processes. While $52 \%$ of Muir Glacier's debris is transported englacially, only $18 \%$ and $19 \%$ of the debris is transported by the equivalent ice facies at Grand Pacific and Margerie Glaciers, respectively. Debris concentration in the diffuse facies of Muir Glacier is more than four times those of Grand Pacific and Margerie Glaciers (Table 1). We believe that the debris distribution at Muir Glacier reflects the relative importance of lateral debris sources (e.g. rockfalls, slides and avalanches) in the narrow valleys through which Muir Glacier flows (Figs 3a and 8a). These sources introduce supraglacial debris to the surface of the glacier where it becomes entrained by snow accumulation and ice metamorphism.

The relative abundance of debris in basal and morainal facies at Margerie and Grand Pacific Glaciers documents the influence of tributary confluences. Dominant zones of debris transport in Grand Pacific are about equally subdivided between morainal $(39 \%)$ and basal ice facies $(43 \%)$. The relatively high contribution of morainal facies must reflect the complex interactions of its multiple tributaries, especially Ferris Glacier (Figs 3b and 8b). In sharp contrast, Margerie Glacier (Figs 3a and 8c) transports nearly $74 \%$ of its debris in the basal ice. Its low englacial-debris flux (Table 2) reflects the influence of fewer tributaries and the wide valley of its upper accumulation area (Hunter and Powell, in press a).

\section{Sediment introduction into the fjord environment}

Debris transported to the terminus of tidewater glaciers is released by a variety of processes (Powell, 1980, 1988; Hunter, 1994) including grain-by-grain melt-out at the ice cliff (ice-cliff melt-out, $D_{\mathrm{m}}$ ), dumping of supraglacial debris during calving (calve dumping, $D_{\mathrm{d}}$ ) and melt-out from icebergs (iceberg-rafting, $D_{\mathrm{i}}$ ), or ablation and meltout at terrestrial margins $\left(D_{\Delta}\right)$.

The debris flux can be partitioned as follows:

$$
D_{\mathrm{t}}=D_{\mathrm{m}}+D_{\mathrm{d}}+D_{\mathrm{i}}+D_{\Delta}
$$

where $D_{\mathrm{d}}$ and $D_{\mathrm{m}}$ add debris to the morainal bank along the grounding line, $D_{\Delta}$ is the debris dumped on to terrestrial parts of the morainal bank (e.g. deltas) and valley sides, and $D_{\mathrm{i}}$ represents debris transport away from the terminus.

From our observations at both terrestrial and tidewater termini, we feel that the lowermost solid facies represents localized seasonal freezing of subglacial sediment, or rapid freezing due to thermodynamic disequilibrium near calving margins. Such layers would experience only local transport from the subglacial slope of a morainal bank to the grounding line. In this regard, we do not treat these layers as adding sediment to the morainal bank, but simply as a form of recycling (freezerecycling: $R_{\mathrm{f}}$ ). The flux of sediment recycled by this mechanism is estimated by sampling the lowermost solid layer along terrestrial sections of termini and similar layers carried to the fjord-water surface by icebergs (Fig. $3 \mathrm{~b})$ that were in contact with the fjord floor prior to calving (Fig. 7; Hunter, 1994). Solid layers stratigraphically higher in the basal ice are, however, added to the calculation of the debris flux (Equation (7)).

Using each glacier's attributes (Table 3), we can calculate the volume of debris released into the fjord environment by these processes. The calving speed $\left(v_{\mathrm{c}}\right)$ is calculated using a modified continuity equation Brown and others, 1982):

$$
v_{\mathrm{c}}=v_{\mathrm{t}}-R-X
$$

where $X$ is the rate of change of glacier length positive for advance; Meier and others, 1980) and $R$ is the melting rate (see Table 3) calculated using the Weeks and Campbell (1973) equation:

$$
R=6.74 \times 10^{-6} v^{0.8} \Delta T / l^{0.2}
$$

where $v$ is the boundary-layer water velocity, $\Delta T$ is the temperature difference between water and ice, and $l$ is a linear measure of the ice cliff in contact with water, either its height in contact with the sea (i.e. water depth, $h_{\mathrm{w}}$; Powell and Molnia, 1989; Syvitski, 1989) or width $\left(w_{\mathrm{c}}\right.$; Powell, 1983, 1988). An average temperature difference $\Delta T)$ of $2.95^{\circ} \mathrm{C}$ was measured by a remotely operated submersible that collected data in front of tidewater termini in Glacier Bay (personal communication from $\mathrm{S}$. Bograd, 1994).

The choice of characteristic length $l$ in Equation (9) depends upon whether the dominant current at the ice cliff is from buoyant upwelling of meltwater or horizontal fjord currents. Melting rates were calculated by substituting $h_{\mathrm{w}}$ for $l$ for Grand Pacific and Muir Glaciers where upwelling along the ice cliffs is important and $w_{\mathrm{c}}$ for Margerie Glacier where tidal currents across the face prevail. Open water $(2-5 \mathrm{~m}$ wide $)$ is common along the ice cliffs of Grand Pacific and Muir Glaciers that indicate the spreading of upwelling fresh water that displaces longitudinal currents. In addition, fjord circulation at the terminus of Muir Glacier was restricted by a shallow morainal-bank sill left behind by grounding-line retreat (Hunter, 1994). In contrast, Margerie Glacier terminates in a hanging valley along the western margin of Tarr Inlet (Fig. 1) where its ice cliff is exposed to tidal currents moving up- and downfjord (e.g. Syvitski and others, 1987). Turbid surface water flows rapidly across the face of Margerie Glacier and forms strong near-surface $<10 \mathrm{~m}$ depth) currents while tidal exchange produces currents at depth.

On this basis, melting rates of 21 and $20 \mathrm{~m} \mathrm{a}^{-1}$ have been calculated for Grand Pacific and Muir Glaciers, respectively, using a boundary-layer velocity of $0.03 \mathrm{~m} \mathrm{~s}$ 
to represent buoyant upwelling following the arguments of Cowan and Powell (1986) and Powell and Molnia (1989), and oceanographic measurements by Mathews and Quinlan (1975). Using terminus width exposed to tidewater $\left(w_{\mathrm{c}}\right)$ and a velocity of $0.25 \mathrm{~m} \mathrm{~s}^{-1}$ estimated from iceberg drifting), a melting rate $\left(R_{\mathrm{m}}\right)$ of $31 \mathrm{ma} \mathrm{a}^{\mathrm{L}}$ has been calculated for Margerie Glacier.

We can calculate the melting flux $\left(Q_{\mathrm{m}}\right)$ and debris volume released due to melting $\left(D_{\mathrm{m}}\right)$ by substituting melting rate $(R)$ for velocity $\left(v_{\mathrm{t}}\right)$ in Equation $(6)$, and $Q_{\mathrm{m}}$ for $Q_{\mathrm{i}}$ in Equation (5) Table 2). $D_{\mathrm{m}}$ ranges from $3.7 \times 10^{4} \mathrm{~m}^{3} \mathrm{a}^{1}$ at Margerie Glacier to $5.0 \times 10^{4} \mathrm{~m}^{3} \mathrm{a}^{\text {I }}$ at Grand Pacific Glacier where most of each terminus is exposed to tidewater. At Muir Glacier, the width of the ice cliff exposed to tidewater diminished from $900 \mathrm{~m}$ in 1978 Brown and others, 1982 to a perimeter of $475 \mathrm{~m}$ around a calving embayment in 1991. The debris released by ice-cliff melting is estimated at $5.8 \times 10^{4} \mathrm{~m}^{3} \mathrm{a}^{1}$ in the early 1990s.

The morainal banks of Grand Pacific, Margerie and Muir Glaciers receive a net addition of $8.4 \times 10^{t}$, $7.8 \times 10^{4}$ and $7.2 \times 10^{4} \mathrm{~m}^{3} \mathrm{a}^{-1}$, respectively, through calve dumping and ice-cliff melt-out. Local recycling of morainal-bank sediment near the grounding line delivers up to $6.2 \times 10^{5}, 1.0 \times 10^{4}$ and $7.2 \times 10^{5} \mathrm{~m}^{3} \mathrm{a}^{-1}$ to the grounding lines of these glaciers Table 2). Icebergrafting $\left(D_{\mathrm{i}}\right)$ accounts for the removal of $1.0 \times 10^{6} \mathrm{~m}^{3} \mathrm{a}^{-1}$ Grand Pacilic), $9.3 \times 10^{5} \mathrm{~m}^{3} \mathrm{a}^{-1}$ (Margerie) and $3.2 \times 10^{5} \mathrm{~m}^{3} \mathrm{a}^{1}$ (Muir), or about $25-96 \%$ of the debris fluxes.

The flux of sediment transported in a deformable bed has been roughly estimated assuming a $60 \mathrm{~cm}$ thick deforming layer (e.g. Humphrey and others, 1993 and a linear velocity profile (Alley, 1991 a). Assuming plug-flow conditions, the average velocity of the deforming layer is about half of the surface velocity, or about 262, 405 and $850 \mathrm{ma}^{1}$ for the Ferris tributary of Grand Pacific Glacier, Margerie and Muir Glaciers, respectively. We use the Ferris tributary here because it is the source of nearly $100 \%$ of the ice discharged into sea water by Grand Pacific Glacier Hunter, 1994). Based on these assumptions, we estimate that $1.3 \times 10^{5}, 2.3 \times 10^{5}$ and $2.2 \times 10^{5} \mathrm{~m}^{3}$ a ${ }^{1}$ could be transported, respectively, to the grounding lines of Grand Pacific, Margerie and Muir Glaciers by deforming layers. However, if soft-bed deformation is more localized, the subglacial sediment flux could be considerably less.

In comparison, the glacifluvial system supplies $7.7 \times 10^{7}, 2.6 \times 10^{7}$, and $6.6 \times 10^{6} \mathrm{~m}^{3}$ a ${ }^{1}$ of sediment to the grounding line at Grand Pacific, Margerie and Muir Glaciers, respectively Hunter, 1994). The glacifluvial flux in Glacier Bay is, therefore, one to two orders of magnitude greater than the total glacial debris flux. The significant contribution of fluvial sediment to the marine environment in Glacier Bay reflects the region's maritime climate and heavy precipitation, snow and ice melt and temperate ice conditions, each of which produce prodigious amounts of water for the glacifluvial system. These factors, along with friable bedrock, produce conditions favoring high sediment yields.

In other regions of the world, Andrews and others (1994) and Elverhoi and others (1995) suggest that in Greenland and Svalbard the glacifluvial input is second- ary, as the relative contribution of the debris flux into the total sediment budget is greater at latitudes higher than Glacier Bay $>59^{\circ} \mathrm{N}$ ). Clearly, the role of glacifluvial transport varies as the rate of ablation increases Hallet and others, in press). Thus, both the glacifluvial sediment flux and the debris flux must be considered in regional comparisons.

\section{CONGLUSIONS}

In this paper, we have described the flux of debris transported in and on the surfaces of the Grand Pacific, Margerie and Muir Glaciers. We have isolated the debris flux from the flux of sediment discharged by outwash streams into the fjord environment to provide constraints on debris transport. The debris flux is governed by several attributes including glacier size, number of tributaries, glacier flow speed, the bedrock geology, substrate and character, thermal regime, local relief and accumulation patterns. Muir Glacier's diffusefacies debris concentration $(\bar{x}=0.6 \%$ by volume) is more than four times greater than those of Grand Pacific and Margerie Glaciers $\sim 0.1 \%$ by volume $)$ and reflects the importance of lateral inputs (e.g. rockfalls, slides, avalanches, eolian transport) in narrow valleys. The proportion of Muir Glacier's debris transported in englacial ice is $52 \%$, with the remaining $48 \%$ being transported in basal and morainal ice facies. In contrast, $18 \%$ of Grand Pacific Glacier's and 19\% of Margeric Glacier's debris flux is transported by englacial ice. Debris transport in Grand Pacilic Glacier is about equally divided between morainal $(39 \%)$ and basal ice facies $(43 \%)$, indicating the importance of medial moraines in debris transport for glaciers with multiple tributaries. Basal ice facies transport nearly $74 \%$ of the total debris flux at Margerie Glacier where englacial ice is relatively clean and there are few medial moraines (Figs $2 \mathrm{~b}$ ) and $8 \mathrm{c}$ ).

Data presented in this paper represent a first attempt to quantify the volume of debris transported by ice to tidewater termini as part of the total sediment flux of glacial systems. In Glacier Bay, glaciers with tidewater termini lose as much as $96 \%$ of their debris to icebergrafting. At Grand Pacific and Margeric Glaciers, less than $10 \%$ of debris is released at the terminus and deposited near the grounding line. This volume is relatively insignificant when compared to the volume of glacifluvial sediment discharged from outwash conduits. Glacifluvial sediment production is as much as two orders of magnitude greater than the debris flux and constitutes $83.698 .6 \%$ of total sediment yields. This relationship, however, may vary in cooler, drier subpolar and polar climates. In addition, our estimates of deforming-bed transport indicate that it may deliver 2-8 times as much sediment to the grounding line as is released by melting of debris-rich ice and dumped during calving events. By developing a better understanding of debris flux and the mechanisms that control grounding-line deposition, our data should be useful in constraining models of glacier sensitivity to sediment dynamics Alley, 1991b) and evaluating process variations under different climatic regimes. 


\section{ACKNOWLEDGEMENTS}

The authors thank B. Hallet, J. Strasser, J. Hardy and two anonymous reviewers for critically reviewing previous versions of the manuscript. Their comments were insightful and informative. Thanks are also forwarded to the National Park Service at Glacier Bay National Park and Preserve for logistical support, and especially to J. Luthy, captain of the M/V Nunatak. Special thanks are given to $\mathrm{L}$. Hunter for her assistance in the field, drafting and editing the numerous versions of the manuscript. Field assistance was also provided by J. Cai. The lead author thanks D. Hirst and E. Josberger for assistance and access to the aerial photograph archives at the U.S. Geological Survey Ice and Climate Project, Tacoma, Washington. Funding was provided by the U.S. National Science Foundation under grant DPP 88-22098 to R.D.P.; the Geological Society of America, Sigma Xi and the Department of Geology at Northern Illinois University to L.E.H.; and U.S. Army CRREL for D.E.L. under the Civil Works Cold Regions Water Resources Program, "Predicting Runoff and Sediment Yield from Partly Glacierized Basins".

\section{REFERENCES}

Agassiz. L. 1840. Éludes sur les glaciers. Neuchàtel, Jent et Gassmann.

Alley, R. B. 1991a. Deforming-bed origin for southern Laurentide till sheets? J. Glaciol., 37 125), 67-76.

Alley, R. B. 19911. Sedimentary processes may cause fluctuations at tidewater glaciers. Amn. Glaciol., 15, 119-124.

American Geological Institute, 1982. AGI data sheets for geology in the field, laboratory, and office. Second edition. Falls Church, VA, American Geological Institute.

Andrews, J. T.. J. D. Milliman, A E. Jennings, N. Rynes and J. Dwyer. 1994. Sediment thicknesses and Holocene glacial marine sedimentation rates in three east Greenland fjords (ca. $68^{\circ} \mathrm{N}$ ). J. Geol., 1026 ), $669-683$.

Bogen, J. 1989. Glacial sediment production and development of hydroelectric power in glacierized areas. Amn. Glaciol., 13, 6-11.

Boulton, G.S. 1970. On the origin and transport of englacial debris in Svalbard glaciers. J. Glaciol., 9 56), 213-229.

Boulton, G.S. 1987. A theory of drumlin formation by subglacial deformation. In Menzies, J. and J. Rose, eds. Drumlin Symposium. Rotterdam, A. A. Balkema, $25-80$.

Boulton, G.S. and R.C.A. Hindmarsh. 1987. Sediment deformation beneath glaciers: rheology and glacier consequences. J. Geophys. Res., 92 B9), 90599082.

Brown, C.S., M. F. Meier and A. Post, 1982. Calving speed of Alaska tidewater glaciers, with application to Columbia Glacier. U.S. Geol. Surv. Prof. Pap. 1258-C.

Chernova. L. P. 1981. Influence of mass balance and run-off on reliefforming activity of mountain glaciers. Amn. Glaciol., 2, 69-70.

Cowan, E. A. and R.D. Powell. 1986. Deposition of cyclically interlaminated sand-and-mud in an ice proximal glacimarine environment. In Program with Abstracts, 9th Biemnial Meeting. American Quaternary .Association, Champagne. Illinois, 74.

Dowdeswell, J. A. and E. K. Dowdeswell. 1989. Debris in icebergs and rates of glaci-marine sedimentation: observations from Spitsbergen and a simple model. \%. Giol., 97, 221-231.

Dowdeswell, J.A. and T. Murray. 1990. Modelling rates of sedimentation from icebergs. In Dowdeswell. J.A. and J. D. Scource, eds. Glacimarine environments: processes and sediments. London, Geological Society, 121-137. Special Publication 53.

Dowdeswell, J.A., M.A. Maslin, J. T. Andrews and I. N. McCave. 1995. Iceberg production, debris rafting, and the extent and thickness of Heinrich layers $\mathrm{H}-1, \mathrm{H}-2$ in North Atlantic sediments. Geology. 23 4), 302-304.

Elverhoi, A. and 6 others. 1995. Late Quaternary sediment yield from High Arctic Svalbard area. 7. Geol., 103, 1-17.

Eyles, C. H., N. Eyles and M. B. Lagoe. 1991. The Yakataga Formation: a Late Miocene to Pleistocene record of temperate glacial marine sedimentation in the Gulf of Alaska. Geol. Soc. Am. Spec. Pap. 261, $159-180$.

Gardner, J.S. and N. K. Jones. 1993. Sediment transpont and yield at the Raikot glacier. Nanga Parbat. Punjab Himalaya. In Schroder, J. F., Jr, ed. Himalaya to the sea. Geolog)', geomorphology and the Quaternary. London. Routledge, 184 197.

Gilbert, G. K. 1905. Crescentic gouges on glaciated surfaces. Geol. Soc. Am. Bull., 17, 303-316.

Goodwin, 1. 1). 1993. Basal ice accretion and debris entrainment within the coastal ice margin, Law Dome, Antarctica. \%. Glaciol., 39 (131). $157-166$.

Gottler, P. 1992. Ice-rafting at a temperate tidewater glacier, McBride Inlet, Glacier Bay, Alaska. M.Sc. thesis, Northern Illinois University.

Gottler. P. and R. D. Powell. 1990. Processes and deposits of icebergrafted debris, Glacier Bay, Alaska. In Milner, A. M. and J. D. Wood, Jr, eds. Proceedings of the Second Glacier Bay Science Symposium, 1988. Anchorage, AK, U.S. Department of the Interior. National Park Service, $56-61$.

Gustavson, T. C. and J. C. Boothroyd. 1987. A depositional model for outwash, sediment sources, and hydrologic characteristics, Malaspina Glacier, Alaska: a modern analog of the southeastern margin of the Laurentide ice sheet. Geol. Soc. Am. Bull., 99 2), 187200.

Hallet, B., L. E. Hunter and J. Bogen. In press. Rates of erosion and sediment evacuation by glaciers: a review of the evidence. Global and Planetary Change.

Heiny, J.S. 1983. Sediment characteristics of rapidly retreating valley glaciers. M.Sc, thesis, Northern Illinois University.

Hicks, D. M., M.J. McSaveney and T.J.H. Chinn. 1990. Sedimentation in proglacial Ivory Lake, Southern Alps, New Zealand. Arct. Alp. Res.. 22 1), 26-42.

Humphrey, N., B. Kamb, M. Fahnestock and H. Engelhardt. 1993. Characteristics of the bed of the lower Columbia Glacier, Alaska. If Geophys, Res, 98 B1), 837-846.

Hunter, L. E. 1994. Grounding-line systems and glacier mass balance of modern temperate glaciers and their effect on glacier stability. Ph.D. thesis, Northern Illinois Lniversity.

Hunter, L. E. and R. D. Powell. In press a. Climatic controls on glacier mass balance in Glacier Bay National Park and Preserve, Alaska. In Engstrom. D., ed. Proceedings of the Third Glacier Bay Science Symposium. Anchorage, AK, U.S. Department of the Interior. National Park Service.

Hunter, L. E. and R. D. Powell. In press b. Effects of ice-proximal sediment dynamics on the stability of Muir Glacier, Glacier Bay, Alaska. In Engstrom, D., ed. Proceedings of the Third Glacier Bay Science Symposium. Anchorage, AK, U.S. Department of the Interior. National Park Service.

Knight, P. G. 1989. Stacking of basal debris layers without bulk freezingon: isotopic evidence from West Greenland. F. Glaciol,, 35 120), 214 216.

Lawler, D., M. Dolan, H. Tómasson and S. Zóphóniasson. 1992. Temporal variability of suspended sediment flux from a subarctic glacial river, southern Iceland. International Association of Hydrological Sciences Publication 210 Symposium at Oslo 1992 - Erosion and Sediment Transport Monitoring Programmes in River Basins), $233-243$.

Lawson, D. E. 1979. Sedimentological analysis of the western terminus region of the Matanuska Glacier, Alaska. CRREL. Rep. 79-9.

Lawson, D. E. 1993. Glaciohydrologic and glaciohydraulic effects on runoff and sediment yield in glacierized basins. CRREL Monogr. 93-2.

Lawson, D. E. and J. B. Kulla. 1978. An oxygen isotope investigation of the origin of the basal zone of the Matanuska Glacier, Alaska. J. Geol., 86 6), 673-685.

Mathews, J. B. and A. V. ()uinlan. 1975. Seasonal characteristics of water masses in Muir Inlet, a fjord with tidewater glaciers. J. Fish. Res. Board Can., 32 10), 16931703.

Mayo, L. R. 1988. Advance of Hubbard Glacier and closure of Russell Fjord. Alaska - environmental effects and hazards in the Yakutat area. U.S. Geol. Surv. Circ. 1016, 4-16.

Meier, M. F. and 7 others. 1980. Predicted timing and disintegration of the lower reach of Columbia Glacier, Alaska. U.S. Geol. Surv. Open Fïle Rep. 80-52.

Milliman, J. D. and J. P. M. Syvitski. 1992. Geomorphic/tectonic control of sediment discharge to the ocean: the importance of small mountainous rivers. 7. Geol.. 100, 525544.

Ovenshine, A. T. 1970. Observations of iceberg rafting in Glacier Bay, Alaska, and the identilication of ancient ice-rafted deposits. Geol. Soc. Am. Bull., 81 (3), $891-894$.

Pelto, M.S. and C. R. Warren. 1992. Relationship between tidewater glacier calving velocity and water depth at the calving front. Amn. 
Glaciol., 15. 115118.

Plafker, G. and W. O. Iddicott. 1976. Glaciomarine deposits of Miocene through Holocene age in the Yakataga Formation along the Gulf of Mlaska margin. In Miller. T.. ed. Recent and ancient sedimentary emiromments in Alaska. Anchorage, AK. Mlaska Geological Society, Q1-023.

Playfair.J. 1802. Illustrations of the Hultonian theory of the Earth. Edinburgh. II. Creech.

Powell, R.1). 1980. Holocene glacimarine sediment deposition by tidewater glaciers in Glacier Bay, Alaska. Ph.D, thesis, Ohio State University.

Powell. R. D. 1981. A model for sedimentation by tidewater glaciers. Inn. Glaciol., 2. $129-134$.

Powell. R. D. 1983. Glacial-marine sedimentation processes and lithofacies of temperate tidewater glaciers, Glacier Bay, Nlaska. In Molnia, B. F., ed. Cilacial-marine sedimentation. New York. etc., Plenum Press, 185-232.

Powell, R. D. 1984a. Glacimarine processes and inductive litholacies modelling of ice shelf and tidewater glacier sediments based on Quaternary examples, Mar. Geol., 57 1 1), 152.

Powcll, R. 1). 1984b. Givide to the glacial geologr of Glacier Bay, southeastem Alaska, Inchorage, AK, Alaska Geological Society. Field gruide for lield wip held in conjunction with 80th Annual Meeting of the Cordilleran Section, Geological Society of America, 30 Mas-1 June 1984, Anchorage, Naska.

Powell, R. D). 1988. Processes and facies of temperate and sub-polar glaciers with lidewater fromls. Boulder. C.O. Geological Society of America. Geological Society of America Short Course Notes.

Powell. R. D. 1991. Grounding-line systems as second-order controls on fluctuations of tidewater termini of temperate glaciers. Geol. Soc. Am. Spec. Pap. 261. 7593.

Powell, R.D. and B. F. Molnia. 1989. Glacimarine sedimentary processes. facies and morphology of the south-southeast Nlaska Shelf and fjords. Mar. Geol., 852 4). $359-390$.

Ramsay, A.C. 1862. On the glacial origin of certain lakes in Swizerland, the Black Forest, Great Britain, Sweden, North America, and elsewhere. Q. 7. Cicol. Soc. London. 18. 185204.

Romnert, L. and D. M. Mickelson. 1992. High porosity of basal till at Burroughs Glacier, southeastern . Maska. (reolog), 209 , $849-852$.

Sharp, M.. J. Jouzel, B. Hubbard and W. Lawson. 1994. The character. structure and origin of the basal ice layer of a surge-type glacier. 7. Glaciol., $40135,327-340$.

Soucher, R. and 8 others. 1994. Stable isotopes in the basal silty ice preserved in the Greenland ice sheet at Summit: environmental implications. Geopheys. Res. Lell., 218 . 693696.

Syvitski, J.P. M. 1989. On the deposition of sediment within glacierinfluenced ljords: oceanographic controls. Mar. Geol., 8524,301 329.

Syvitski, J. P. M.. D. C. Burrell and J. M. Skei. 1987. Foords: processes and products. New York. Springer-Verlag.

Weeks. W. F. and II, J. Campbell. 1973. Icebergs as a fieshwater source: an appraisal. \%. Glaciol.. $1265,207-223$.

MS received 12 May 1995 and accepled in revised form 31 .August 1995 